\title{
SEAS IN SEA: EMERGENCE, DEVELOPMENT, REBRANDING AND SUSTAINABILITY OF SOUTHEAST ASIAN STUDIES IN MALAYSIA*
}

\author{
Hanafi Hussin ${ }^{1} \&$ Mala Rajo Sathian ${ }^{2}$ \\ ${ }^{1}$ First author \\ 1,2Department of Southeast Asian Studies \\ Faculty of Arts and Social Sciences \\ Institute of Ocean and Earth Sciences (IOES) \\ 2Thai Studies Program \\ University of Malaya \\ (hanafih@um.edu.my, malarajo@um.edu.my) \\ DOI: https://doi.org/10.22452/jati.vol23no1.1
}

\begin{abstract}
This article provides an introductory and brief overview of the research, publications, and achievements of Southeast Asian Studies in Malaysia, in particular, the role of the Department of Southeast Asian Studies at the University of Malaya. It briefly revisits the pre- and post-colonial times, when the subject of Southeast Asian Studies appealed to academics, administrators, and foreign experts. Since 1975, the Department has not only played the role of training young researchers in different issues on Southeast Asia but also provided a platform to local and foreign researchers to publish their scholarly work in JATI-Journal of Southeast Asian Studies and Borneo Research Journals that are both produced by the department annually.

Keywords: Southeast Asian Studies, Department of Southeast Asian Studies, teaching, research, publication.

*an extended paper of Hanafi Hussin (2017) with corrected facts on the history of Southeast Asian Studies Programme at the Department of Southeast Asian Studies, Faculty of Arts and Social Sciences, University of Malaya.
\end{abstract}

\section{Introduction}

In the last decade, Southeast Asian Studies (hereafter SEAS) has witnessed a decline in various universities and institutions in the west. On the other hand, 
in Southeast Asia, this field of study is on the rise (Placzek, 2014). Indonesian scholars Muhadi Sugiano and Bambang Purwanto claimed that Southeast Asian Studies is a "baggage of colonial construct while ASEAN Studies was more locally engineered" (Sathian, 2015), indicating the declining popularity of the former in Indonesia. However, SEAS is rapidly developing as a formidable field of study in Malaysia. Although it did not gain importance until the 1970s, in the last four decades, there has been a dramatic increase in the number of research institutions, academics, researchers, graduates, and publications related to SEAS in the country. The department of SEAS, University of Malaya, has taken the pioneering step towards developing this field of study in Malaysia since its establishment in 1979.

Despite its long existence, the available literature on SEAS hardly mentions or refers to the research, publications, and efforts by the department in advancing SEAS in Malaysia for the last forty years. This article aims to provide a brief overview of the progress in the field of SEAS in Malaysia and to identify the limitations, issues and future challenges for the next generation of researchers focusing on SEAS in Malaysia as well as those within the region. The article will conclude with suggestions for possible ways to rebrand the field of SEAS to remain relevant in the future.

Data for the present article was obtained through a brief historical overview of the discipline in Southeast Asia, paying attention to scholarly articles published inside and outside of Malaysia in the field of SEAS. We noted that the progress and achievements of individual researchers and academic institutions are closely linked to the general 'institution/al' growth of centres or departments devoted to teaching and researching SEAS. By extension, we are concerned that with the gradual decline and discontinuation of SEAS programmes, the field of SEAS would be negatively impacted. Therefore, our urgent plea is for rebranding and rethinking SEAS.

\section{Southeast Asian Studies Outside of Southeast Asia}

SEAS originated in the west (Tzeng, Richter, \& Koldunova, 2018). There are some established centres of Asia, South and East Asian Studies in the United States and many others in Europe (Leiden, Freiburg, Uppsala, etc.).

In the West, Southeast Asian Studies has been taught either as a compulsory or optional subject. However, generally, it is approached as a multi-disciplinary module drawing theoretical, conceptual and methodological support from various social science disciplines, such as anthropology, history, geography, sociology, politics, and economics. 
Table 1: The Relevant Area Studies Institutions in the United States

\begin{tabular}{|l|l|l|}
\hline No & University & The relevant institution \\
\hline 1 & Arizona State University & Center for Asian Research \\
\hline 2 & Columbia University & Weatherhead East Asian Institute \\
\hline 3 & Cornell University & The Southeast Asia Program \\
\hline 4 & Johns Hopkins University & School of Advanced International Studies \\
\hline 5 & Northern Illinois University & Center for Southeast Asian Studies \\
\hline 6 & Ohio University & Southeast Asian Studies \\
\hline 7 & University of Alabama & Asian Studies \\
\hline 8 & University of California, Berkeley & Center for Southeast Asia Studies \\
\hline 9 & University of California, Los & Center for Southeast Asian Studies \\
\hline 10 & Angeles & \\
\hline 11 & University of California, Riverside & SEATRiP \\
\hline 12 & University of Hawai'i, Manoa & Center for Asian Studies \\
\hline 13 & University of Michigan & Center for Southeast Asian Studies \\
\hline 14 & University of Oregon & Center for Asian and Pacific Studies \\
\hline 15 & University of Pittsburgh & Indo-Pacific Council \\
\hline 16 & University of Washington & Southeast Asia Center \\
\hline 17 & University of Wisconsin, Madison & Center for Southeast Asian Studies \\
\hline 18 & Yale University & Council on Southeast Asia Studies \\
\hline
\end{tabular}

Source: The United States-Indo Society (n.d.).

The institutionalization of SEAS enabled researchers and practitioners to investigate the regional conditions and processes from the regional and international, historical, ethnographic and cultural perspectives. The main agenda of developing Southeast Asian Studies in different parts of the world including Russia was to treat Southeast Asia as a distinct region as well as a unique area of study (Koldunova, 2018). Although there are obvious overlaps, as is usually the case with area studies, the field is increasingly being reclustered or extended into areas such as Global Studies (Japan), Cultural Studies and Asian Studies (Brunei).

\section{The Emergence of Southeast Asian Studies in Malaysia}

Since western colonizers occupied most of Southeast Asia region, the origin of Southeast Asian studies in Southeast Asia has to be traced back to the colonial history. During the colonial period, The University of Rangoon and Raffles College in Singapore were important training places for the British administrators, scholars, and academics. After the Pacific War (1941-1945), a significant change in the center of scholarship took place. By 1948, the British had no base in the University of Rangoon and Burma. However, during the 
1950s and 1960s, British academics and researchers remained present in Singapore, Malaysia, and Hong Kong, and led to Southeast Asia emerging as a globally defined area for scholarly research. The University of Malaya (UM) emerged when in 1949 Raffles College and King Edward VII College of Medicines were merged and its campus expanded to Kuala Lumpur in 1959. Many academic experts were appointed to the University of Malaya (King, 2013). Reid (1988, 1993) has provided a detailed list of researchers, scholars and contributors to the making of SEAS. King (2013) claims that then the scholars were closely interconnected and networked. The numbers of scholars were small. Thus, career paths of individual researchers crossed. They were supervised and trained by a small number of senior academicians. They also examined issues from an established base in a particular discipline such as anthropology, political science, language, history, literature, geography, economics and economic history.

In 1975, the Department of Southeast Asian Studies was established at the University of Malaya. At that time, the UM was the sole institution that offered a full-time bachelor and postgraduate degree programme on Southeast Asian Studies in the region. The programme was designed in line with the national policy directions and the state of the economic, political, and cultural dynamism of Southeast Asian countries. Some believed that its establishment was in response to the 1967 ASEAN Declaration to promote SEAS. Up to the present, the Department of Southeast Asian Studies at the UM remains the only department in Malaysia that offers an academic degree in SEAS. Over time, distinct approaches and ways of investigating, framing, and examining the Southeast Asian region were developed. On the other hand, the programme continued to face academic challenges specifically on its relevance to contemporary society and evolving needs. In particular, the major challenge was the perception that the programme had no direction and lacked a discipline-based specialization.

The scenario was far from the truth. With the combined and concentrated efforts of local Malaysian scholars such as K. T. Joseph, Krishen Jit, Shaharil Talib Robert, Khadijah Muhammed, among others, and with help from foreign academic visitors, the programme produced its first batch of graduates majoring in SEAS 1977. The programme encouraged students to adopt a multidisciplinary approach learning, which exposed them to many other disciplines within the social sciences, law, and economy, in order to develop their capacity to study and analyze diverse issues in SEAS through a broad perspective. Since the programme was modelled after the conventional SEAS, centered in the US, students were required to master a Southeast Asian 
language such as Thai, Filipino, and Burmese, that were taught at UM's Language Center. The language learning component distinguished graduate students from Southeast Asian Studies from other related fields of studies. Southeast Asian language skills enabled graduates from the department to gain an advantageous position in the workforce. Many of these graduates were recruited as diplomatic officers in the Ministry of Foreign Affairs, Malaysia and other jobs such as lecturers, teachers, and administrators.

Graduates from the first batch of SEAS Programme as well as those from other disciplines were recruited to become part of the department and social science faculty. In more recent time, graduates from the department have furthered the interest to explore Southeast Asia for knowledge gains as well as motivated by the marketability of graduates of SEAS in the workforce. This is reflected by the increasing number of new admissions into the Master of Arts (MA) in SEAS programme offered by the Department since 2009. The student intake comprising both local and international students has grown steadily since the early years of the programme.

\section{Structure and Design of SEAS as Area Studies in Malaysia}

Generally, following the establishment of respective departments and programmes of SEAS, it becomes mandatory for the undergraduates to pass the designed curricula developed by the academic staff in different phases of history (Curaming, 2017). The structure of the programme and curricula at the Department of SEAS, UM, was designed, taking into account the availability and eligibility of the academics and their compatibility with the needs of Malaysian society. Hanafi Hussin (2017) has noted, three main themes of study and research undertaken at the Department of SEAS UM since its inception.

- Broad socioeconomic and sociocultural studies (1975-1990's)

- Discipline focus on history, maritime, anthropology and performing arts of Southeast Asia (1990's-early 2000)

- General/multi-disciplinary study of the region incorporating a focus on labour, migration, political development and conflict as well as ASEAN (the 2000s - present)

\section{Empowering through Research and Publications}

Research and publications have played a significant role in empowering and advancing the discourse on SEAS. The pioneering group of scholars and students of SEAS at the UM were well-aware of the 'conventional' approaches 
developed to study the subjects in Southeast Asia. These approaches were framed from the western or orientalist perspective noted in area studies (Goh, 2011). Wider discourse on Southeast Asia was made available through seminar presentations, discussions, and dialogues with other scholars at the local and international levels. The department invited many international scholars through networking and collaborative programmes with partner institutions. In international events, various distinguished scholars including Virgilio Enriquez, Charnvit Kasetsiri, Reynaldo Ileto, Chaiwat Satha Anand, Azyumardi Azra, Carmen Abu Bakar, Maris Diokno, Taufik Abdullah, among others, were invited as keynote speakers to the occasional seminars and the biennial international conference on Southeast Asia (ICONSEA). Many among them have returned as visiting professors and research fellows. Many of these names also included founding members of the SEASREP, an organization that grew out of Southeast Asia with the intention to promote and encourage scholarship from within the region. The 'homegrown' concept was, in the words of Shamsul Amri, a process of rebranding SEAS. Claiming that "personalities play an important role in the trajectories of SEAS," Shamsul reminds us of the pioneering contribution of these founding members of SEASREP (Southeast Asia Regional Exchange Program) and a few other prominent scholars from the region in advancing and sustaining SEAS (Shamsul Amri Baharuddin, 2017).

In many of the exchanges and conferences, prominent scholars have shared their research findings and understandings of the issues in Southeast Asia from their research and observations. Maris Diokno, for instance, was invited to share her understanding of the geography and history of the Southeast Asian region under the Southeast Asia Travelling Classroom Programme initiated by the SEASREP. The programme also served as a forum for meeting with other renowned scholars including Charnvit Kasetsiri, who discussed his ideas on tangible and intangible cultural heritage in Southeast Asia comparing the Greater Mekong Subregion with Malaysia/island Southeast Asia perspectives. The programme on Southeast Asian Studies expanded its discourse by organizing bi-annually, the International Conference on Southeast Asia (ICONSEA) since 2005. Since then, the conference has become a major platform to debate and discuss different topics and issues in light of the emerging trends and needs of the contemporary societies.

The current generation of scholars at the Department of SEAS has continued to contribute to the field through research and publications. In addition to actively publishing in reputable and internationally accredited 
journals, from 1995, with the technical support of the department, the UM has been publishing JATI-Journal of Southeast Asian Studies. JATI provides a platform for scholars not only in Malaysia but also in the region to actively engage with each other and share their scholarly findings. JATI, as indicated by David Martin Jones (2017) of King's College, is "one of the few indigenous journals, to focus on the complex web of regional and international challenges that confront local cultural, religious and political practices in the so-called century of the Asia Pacific." As can be viewed in recent publication (2017), JATI promotes critical research on different interrelated issues within the region concerning the geopolitics of the region as well as those pertaining to ASEAN (see for example JATI, 22[1], 2017 for papers by Bui Hong Hanh; Leishangthem Bimolchand Singh; Shirley V. Ramesh; Hadje Cresencio Sadje; and Frida Rahmita). The same volume also contains articles on contemporary and traditional culture and politics in the region (see papers by Afriadi bin Sanusi; Widjajanti Santoso; Meita Istianda; Ahmad Farid Abdul Jalal, Rahimin Affandi Abd. Rahim, Siti Maimunah Binti Kahal and Muhd Imran Abd Razak; and Chaleomsak Bunnam, Idsaratt Rinthaisong, and Anuwat Songsom in JATI, 22[1], 2017) and papers on current issues related to arts and socio-culture (see papers by Paolo Miguel M. Vicerra; Reithy Kieth Chhem; and Siti Fariza Md. Nor and Sarena Abdullah in JATI, 22[1], 2017). This wide-ranging collection provides a distinctively South East Asian perspective on contemporary and past practices in the region (Jones, 2017). The 2017 issue of JATI is also the first volume that is indexed under Emerging Sources Citation Index (ESCI), by the Web of Science. Since 2007, the department has also been producing the Borneo Research Journal that devotes attention to scholarship concerning Borneo Island, simultaneously reflecting the leanings of the department toward maritime/ island Southeast Asia.

\section{Rebranding SEAS in Malaysia for Sustainability and Relevancy}

As indicated above, SEAS is considered residual, from the British colonial era. Thus, some scholars noted the direction-change from conventional SEAS towards ASEAN Studies as a way for SEAS to remain relevant (Kasetsiri, 2013; Sathian, 2015). The 'surrogacy' of SEAS with ASEAN Studies would limit the field of Southeast Asian area studies to issues and development concerning the 
association (ASEAN). Kasetsiri (2013) argues that ASEAN studies is a part of SEAS, irrespective of its origin and early scholarship in the field.

The preservation of Southeast Asian scholarly literature is enabled through retaining SEAS as an area of study. The Department of SEAS at the $\mathrm{UM}$ is contributing to the field by providing education and knowledge to the future generation through its evolving curriculum. It gives an important place to critical and comparative discourse in the postgraduate degree programme and stimulates quality research projects and publications. The niche of the department in the teaching and learning of SEAS is the emphasis on a multidisciplinary approach, particularly which included fieldwork (experiential) component as well as a slant towards local (regional) 'cultural particularism.' This approach, we believe, would lend strongly towards the ASEAN centrality framework that encourages perspectives of 'inter-locking connections' from within (Anthony Milner, observations based on an evaluation of teaching curriculum, SEAS Department, UM, February 2018).

Institutionalization and internalization of Southeast Asian issues and problems through SEAS are one of the main agendas of the department, and it has been able to show progress in this regard. Since 1975, the Department has been able to promote SEAS as envisaged in the 1967 ASEAN Declaration. It has expert scholars in a wide range of areas in the Southeast Asian context that include politics and international affairs, labour and economy, minorities and political conflict, migration, maritime economy, fisheries, agriculture, culture and performing arts, ASEAN and Regionalism as well as expertise in all the major Southeast Asian languages.

However, at the same time the department is facing structural and internal challenges and limitations. The sustainability and relevancy of a compulsory language component have had to be reviewed to provide students option to exchange language learning with other modules in the department. However, the emphasis on taking modules mostly from within the SEAS Department has been noted to create a 'fortress structure' that limit interdepartment learning and obstruct, to some extent, a truly multi-disciplinary approach.

The rebranding of the field needs to be embarked upon by taking into consideration human resource limitations, contemporary student needs and interests as well as a contribution to knowledge. On the latter, Barbara Watson Andaya observed that SEAS is "poorly developed in the region" (Andaya, 2017). Alluding to the phenomenon of "less scholarly tension" Andaya noted the lack of debate, engagement and contemplation in issues pertaining to Southeast Asia from within the region. This may, on hindsight, be a likely 
reason for the lack of theoretical contribution to the field from 'native' Southeast Asian scholars, a point made clear by Ariel Heryanto (2002) in his paper "Can There Be Southeast Asians in Southeast Asian Studies?"

Taking the cue from Shamsul Amri Baharuddin (2017) that rebranding SEAS first took place in the region with the birth of SEASREP in 1995, the present paper suggests that attempts to 'centre' Southeast Asians and Southeast Asia in the field of Southeast Asian enquiry received a further helping hand in the post 1997 Financial Crisis era. Sathian (2015) notes that after the economic bubble burst, "there was a need to unpack, understand and 'de-myth' the Asian Values and the process of decolonization." This was followed by a wave of democratization and decentralization processes as well as the rise of China and India as economic powers. Added to this was the increasing role and presence of Plus 3 dialogue partners in ASEAN Summits that served to enhance the relevance of SEAS (Sathian, 2015, p. 91).

The reality is that globalization is irreversible. Although Southeast Asia is itself a concept of geography and a mosaic of cultures, knowledge on the region appears to be most pronounced in clustered neighbourhoods. SEAS has initiated an openness to mobility programme namely through academic exchange programmes that encourage student mobility across borders. This approach enables and hastens the rebranding of SEAS through encounters and interactions between different dimensions of Southeast Asian society leading to a pragmatic approach to consensus-building in the region.

\section{Conclusion}

The SEAS Programme offered at the University of Malaya is an important educational, training and scholarly research platform on Southeast Asia in Malaysia. Research produced here has complemented western scholarly work and added a local voice to the study of the region in the region, Malaysia in this specific case.

The programme should be mindful of its relevance to the current generation, and its development and progress should be inline with the changes in contemporary scholarly needs of Southeast Asia. As indicated by Andaya (2017), "Southeast Asia has changed, so too the world." It is indeed a loud reminder to review and rethink SEAS in the region! 


\section{References}

Afriadi bin Sanusi. (2017). Perkembangan pembanterasan rasuah di Indonesia (The development of corruption eradication in Indonesia). JATI-Journal of Southeast Asian Studies, 22(1), 58-71.

Ahmad Farid Abdul Jalal, Rahimin Affandi Abd. Rahim, Siti Maimunah Binti Kahal, \& Muhd Imran Abd Razak. (2017). Jalinan intelektual dan persaudaraan Islam Aceh di Pahang (The Aceh's intellectual and Muslim brotherhood linkages in Pahang). JATI-Journal of Southeast Asian Studies, 22(1), 103-127.

Andaya, B. W. (2017). Rethinking Southeast Asian Studies in a globalized world (Keynote Address). The 7th International Conference on Southeast Asia (ICONSEA), University of Malaya, 6 December.

Bui, H. H. (2017). The United States and Vietnam ties in the context of United States - ASEAN relations. JATI-Journal of Southeast Asian Studies, 22(1), $1-8$.

Bunnam, C., Rinthaisong, I., \& Songsom, A. (2017). Structural equation model of causal factors predominating the collaboration between public sectors and community organisations to inhibit the insurgency in the unrest areas of the Southernmost Provinces. JATI-Journal of Southeast Asian Studies, 22(1), 85-102

Chhem, R. K. (2017). In quest of Angkorian medicine Buddha and Boddhisatva: New archaeological evidence. JATI-Journal of Southeast Asian Studies, 22(1), 128-138.

Curaming, R. (2017). From Southeast Asian Studies to ASEAN Studies: A changing geopolitics of knowing? Paper presented at the International Convention of Asia Scholars (ICAS), Chiangmai, Thailand, 20-23 July.

Frida Rahmita. (2017). Capital Punishment for Drugs Trafficking in Southeast Asia: A Violation of Human Rights Law? JATI-Journal of Southeast Asian Studies, 22(1), 158-169.

Goh, B. L. (Ed.). (2011). Decentring and diversifying Southeast Asia: Perspectives from the region. Singapore: Institute of Southeast Asia.

Hanafi Hussin. (2017). Between "conventions" and "institutionalizations": Southeast Asian Studies in Malaysia. Regional Journal of Southeast Asian Studies, 2(2), 132-138.

Heryanto, A. (2002). Can there be Southeast Asians in Southeast Asian Studies? Moussons, 5, 3-30.

Jones, D. J. (2017). Editorial JATI 22, 2017. JATI-Journal of Southeast Asian Studies, 22(1), i-ii. 
Kasetsiri, C. (2013). Special feature: Southeast Asian Studies: Crisis or opportunity? Southeast Asian Studies in Thailand. CSEAS Newsletter, $68,15-17$.

King, V. T. (2013). British perspectives on Southeast Asia and Continental European comparisons: The making of a region. In Park S. W. \& V. T. King (Eds), The historical construction of Southeast Asian Studies: Korea and beyond (pp. 265-323). Singapore: Institute of Southeast Asian Studies.

Koldunova, E. (2018). Southeast Asian Studies in Russia: Agents against structural limits. In A. Tzeng, W. L. Richter \& E. Koldunova (Eds.), Framing Asian Studies: Geopolitics and institutions (pp. 165-188). Singapore: ISEAS - Yusof Ishak Institute.

Meita Istianda. (2017). Indonesia, the world's maritime spindle brief analysis of economy and politics policy in Jokowi's regime. JATI-Journal of Southeast Asian Studies, 22(1), 72-84.

Placzek, J. (2014). Review of the book The historical construction of Southeast Asian Studies: Korea and beyond, by Park S. W. \& V. T. King. Pacific Affairs, 87(3), 636-639.

Ramesh, S. V. (2017). The ASEAN single market: A comparative study. JATIJournal of Southeast Asian Studies, 22(1), 9-25.

Reid, A. (1988). Southeast Asia in the age of commerce, 1450-1680, Vol. 1: The land below the winds. New Haven: Yale University Press.

Reid, A. (1993). Southeast Asia in the age of commerce, 1450-1680, Vol. 2: Expansion and crisis. New Haven: Yale University Press.

Sadje, H. C. (2017). The tragedy of Rohingya people, their tragedies or ours? A Filipino's reflection on the role of ASEAN Community. JATI-Journal of Southeast Asian Studies, 22(1), 48-57.

Santoso, W.M. (2017). The Anti Corruption Issue and the Changing Social Relationship in K- Drama: Indonesian Perspectives. JATI-Journal of Southeast Asian Studies, 22(1), 187-203.

Sathian, M. R. (2015). Approaches to Southeast Asian Studies: Beyond the "comfort zone. Suvannabhumi: Multi-disciplinary Journal of Southeast Asian Studies, 7(1) 89-103.

Shamsul Amri Baharuddin. (2017). Rebranding SEAS (Keynote Address). The 7th International Conference on Southeast Asia (ICONSEA), University of Malaya, 7 December. 
Singh, L. B. (2017). ASEAN's initiatives in the South China Sea dispute: Quest for peace and stability in the Indo-Pacific region. JATI-Journal of Southeast Asian Studies, 22(1), 26-47.

Siti Fariza Md. Nor, \& Sarena Abdullah. (2017). Through the Western eyes: Analysing the strategy of subversion in Yee I-Lann's picturing power (2013) Photomontages. JATI-Journal of Southeast Asian Studies, 22(1), 204-219.

The United States-Indo Society. (n.d.). Southeast Asia/Indonesia Studies programs in the United States. Retrieved from http://www.usindo.org/education-links/southeast-asia-studies-centersin-the-united-states/

Tzeng, A, Richter, W. L., \& Koldunova, E. (2018). Introduction: Framing Asian Studies. In A. Tzeng, W. L. Richter \& E. Koldunova (Eds.), Framing Asian Studies: Geopolitics and institutions (pp. 1-20). Singapore: ISEAS Yusof Ishak Institute.

Vicerra, P. M. M. (2017). Teenage fertility and risk of pregnancy: Sociocultural correlates in the Philippines. JATI-Journal of Southeast Asian Studies, 22(1), 170-186.

Date Received: 15 November 2017 Date of acceptance: 15 April 2018 